\title{
PEMETAAN ZONA TANGKAPAN IKAN (FISHING GROUND) MENGGUNAKAN CITRA SATELIT TERRA MODIS DAN PARAMETER OSEANOGRAFI DI PERAIRAN DELTA MAHAKAM
}

\author{
Radik Khairil Insanu \\ Program Studi Geoinformatika, Politeknik Pertanian Negeri Samarinda \\ Email: ra013f@gmail.com
}

\begin{abstract}
As a maritime country, Indonesia has a comparative advantage in the potential of marine and fishery resources. The parameters of the distribution of sea surface temperature and the distribution of chlorophyll-a can be used for the determination of the fish catch zone in the Mahakam Delta waters area. By knowing the fishing ground, fishermen can maximize the potentiallity of the fish capture. The purpose of this study was to determine the spatial distribution of ground and chlorophyll-a temperatures and to map potential fishing ground zones. The analysis in this study was determined from the distribution of chlorophyll-a obtained with ATBD 19 MODIS band 10 and 12 algorithms and sea surface temperature distribution on ATBD 25 MODIS bands 20, 31 and 32 using images in March, April, July, September and October 2016. Image processing results obtained sea surface temperature in March, April, July, September and October averaged $27^{\circ} \mathrm{C}$ to $30^{\circ} \mathrm{C}$. Only in March the average sea surface temperature has a low temperature. Distribution of chlorophyll-a in 2016 was little identified in September, April and March, whereas in October and July chlorophyll-a was many identified. Determination of high potential catchment zone was having a sea surface temperature of about $27^{\circ} \mathrm{C}-30^{\circ} \mathrm{C}$ with high chlorophyll-a value, so that if sea surface temperature and chlorophyll-a conditions were not suitable, it was called a low catchment zone. The low zone of fish catch is scattered to the north and center of the Mahakam delta, as well as in the middle of the makasar strait. The high zone of fish catch is scattered to the south of the Mahakam delta, as well as in the middle of the makasar strait.
\end{abstract}

Keywords: fishing ground, algorithm, chlorophyll-a, sea surface temperature, TERRA MODIS

\begin{abstract}
Abstrak
Sebagai negara maritim, Indonesia memiliki keunggulan komparatif dalam potensi sumberdaya perikanan dan kelautan. Parameter persebaran suhu permukaan laut dan persebaran klorofil-a dapat digunakan untuk penentuan zona tangkapan ikan pada daerah perairan Delta Mahakam. Dengan mengetahui zona tangkapan ikan, nelayan dapat memaksimalkan potensi hasil tangkapan ikan. Tujuan penelitian ini untuk menentukan distribusi spasial suhu permukaan tanah dan klorofil-a serta memetakan zona potensi ikan. Analisa pada penelitian ini ditentukan dari persebaran klorofil-a yang didapatkan dengan algoritma ATBD 19 MODIS band 10 dan 12 dan persebaran suhu permukaan laut pada algoritma ATBD 25 MODIS band 20, 31 dan 32 dengan menggunakan citra pada bulan Maret, April, Juli, September dan Oktober tahun 2016. Hasil pengolahan data citra didapatkan, suhu permukaan laut pada bulan Maret, April, Juli, September dan Oktober rata-rata $27^{\circ} \mathrm{C}$ sampai dengan $30^{\circ} \mathrm{C}$. Hanya pada bulan maret yang suhu permukaan lautnya rata-rata memiliki suhu yang rendah. Sebaran klorofil-a pada tahun 2016 teridentifikasi sedikit pada bulan September, April dan Maret, sedangkan pada bulan oktober dan juli banyak teridentifikasi klorofila. Penentuan zona potensi tinggi tangkapan ikan yaitu memiliki suhu permukaan laut sekitar $27^{\circ} \mathrm{C}-30^{\circ} \mathrm{C}$ dengan nilai klorofil-a nya tinggi, sehingga apabila kondisi suhu permukaan laut dan klorofil-a tidak sesuai disebut zona rendah tangkapan ikan. Zona rendah tangkapan ikan tersebar di sebelah utara dan tengah delta Mahakam, serta di tengah selat makasar. Zona tinggi tangkapan ikan tersebar di sebelah selatan delta Mahakam, serta di tengah selat makasar.
\end{abstract}

Kata Kunci : Zona Tangkapan Ikan (fishing ground), algoritma, klorofil-a, suhu permukaan laut, TERRA MODIS 


\section{PENDAHULUAN}

\section{Latar Belakang}

Negara Indonesia memiliki luas wilayah hampir dua pertiganya berupa laut, oleh karena itu sering disebut sebagai negara maritim. Sebagai negara maritim, Indonesia memiliki keunggulan komparatif dalam potensi sumberdaya perikanan dan kelautan. Menurut hasil evaluasi berdasarkan data dan informasi yang ada sampai saat ini secara keseluruhan menunjukkan perkiraan potensi lestari sumberdaya perikanan laut sebesar 6,6 juta ton/tahun dengan perkiraan sebesar 4,5 juta ton/tahun terdapat di perairan ZEE Indonesia (Murrachman 2006). Menurut data dari Dinas Kelautan dan Perikanan di Kutai Kartanegara, produksi perikanan pada tahun 2010 terealisasi sebesar 132.065,94 ton dari target produksi sebesar 119.187,00 ton, dengan nilai produksi Rp. 3.301.648.500,-. Kenaikan produksi ini dicapai dari kegiatan penangkapan 74.784 ton dan kegiatan budidaya sebesar 57.281,94 ton. Jika dibandingkan produksi perikanan pada tahun 2009 sebesar 93.467,0 ton dengan nilai produksi sebesar Rp. 2.063.504.000,- maka kenaikan produksi yang dicapai sebesar 41,29 persen. Produksi ini dicapai dari kegiatan penangkapan 52,045 ton dan budidaya 41.440 ton.

Akan tetapi, masih kurangnya teknologi yang digunakan oleh nelayan Indonesia mengakibatkan pemanfaatan potensi sumberdaya perikanan dan kelautan kurang maksimal. Oleh karena itu, perlu adanya suatu penelitian mengenai daerah potensi tangkapan ikan yang bisa membantu nelayan mengetahui dimana tempat ikan berkumpul dengan menggunakan teknologi penginderaan jauh, yaitu dengan data citra MODIS. Penentuan posisi tangkapan ikan dapat diprediksi dari persebaran spasial parameter suhu permukaan laut dan penyebaran klorofil-a.

Citra satelit yang digunakan dalam pemetaan wilayah perairan Indonesia antara lain citra satelit TERRA. Citra satelit TERRA (EOS AM) dan AQUA (EOS PM) membawa sensor Moderate Resolution Imaging Spectroradiometer (MODIS) yang dapat mendeteksi distribusi kandungan klorofil-a distribusi suhu permukaan laut. Moderate Resolution Imaging Spectroradiometer (MODIS) mengamati seluruh permukaan bumi setiap 1-2 hari dengan whiskbroom scanning imaging radiometer. MODIS dengan lebar view/tampilan (lebih $2300 \mathrm{~km}$ ) menyediakan citra radiasi matahari yang direfleksikan pada siang hari dan emisi termal siang/malam diseluruh penjuru bumi. Resolusi spasial MODIS berkisar dari 250-1000 m, (Janssen dan Huurneman 2001). Kandungan klorofil dan suhu permukaan laut merupakan data yang penting dalam menentukan persebaran daerah ikan. Data ini juga diharapkan dapat membantu menghemat biaya operasional serta meningkatkan hasil tangkapan nelayan dalam menentukan daerah penangkapan ikan yang berpotensi.

Dengan melihat besarnya potensi ikan di perairan Indonesia khususnya perairan Delta Mahakam, maka dilakukan penelitian pada daerah perairan Delta Mahakam untuk mengetahui potensi daerah tangkapan ikannya dengan menggunakan satelit TERRA MODIS. Parameter yang digunakan yaitu distribusi spasial suhu permukaan laut (SPL) dan konsentrasi klorofil-a untuk pembuatan peta prediksi daerah potensi tangkapan ikan (fishing ground) agar memudahkan dan menambah efektivitas nelayan Indonesia dalam penangkapan ikan, khususnya ikan pelagis.

\section{Perumusan Masalah}

Perumusan masalah dalam penelitian ini adalah "Bagaimana memetakan potensi daerah tangkapan ikan dengan parameter distribusi suhu permukaan laut (SPL) dan konsentrasi klorofil-a menggunakan citra satelit TERRA MODIS".

\section{Batasan Masalah}

Penelitian yang dilakukan memiliki batasan masalah adalah sebagai berikut :

a. Citra satelit yang digunakan adalah citra satelit TERRA MODIS

b. Pemetaan lokasi penangkapan ikan dalam studi ini menggunakan parameter distribusi spasial suhu permukaan laut dan distribusi klorofil-a

\section{Tujuan Penelitian}

Tujuan dari kajian ini adalah sebagai berikut:

a. Menentukan distribusi spasial suhu permukaan laut (SPL) 
b. Menentukan distribusi kandungan klorofil-a dengan menggunakan data satelit TERRA MODIS yang berguna untuk menunjukkan tingkat kesuburan perairan.

c. Memetakan dan mengkaji potensi daerah tangkapan ikan di Delta Mahakam, Kabupaten Kutai Kertanegara, Kalimantan Timur dengan parameter suhu permukaan laut (SPL) dan distribusi klorofil-a.

\section{METODOLOGI PENELITIAN}

\section{Waktu dan Tempat Penelitian}

Penelitian dilakukan selama 1 tahun. Tempat penelitian dilaksanakan di wilayah perairan Delta Mahakam, Kabupaten Kutai Kertanegara, Kalimantan Timur. Pengambilan titik sampel diambil di sebelah utara Delta Mahakam daerah Kecamatan Muara Badak sebanyak 15 titik sampel air. Waktu pengambilan data di lapangan dilakukan pada tanggal 4 Juni 2016 dan tanggal 11 Juni 2016.

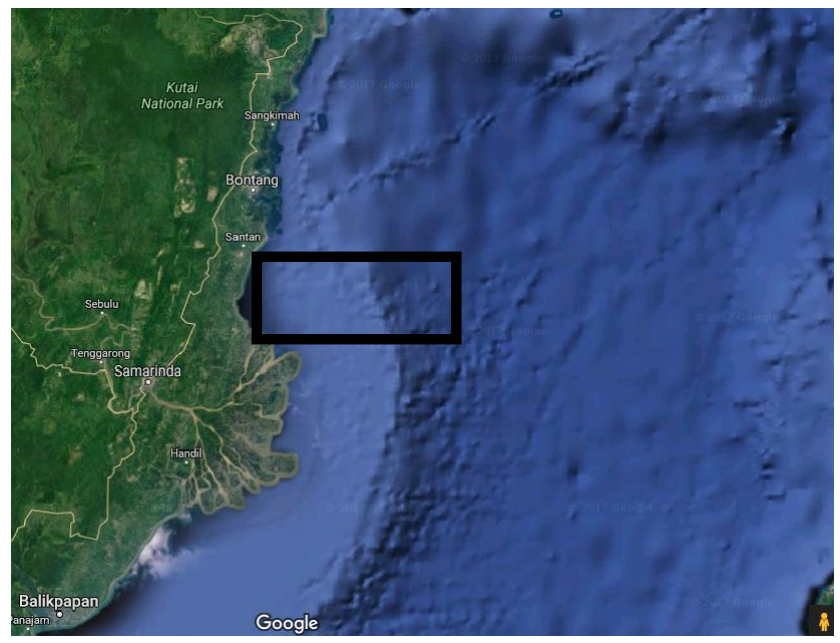

Gambar 1. Lokasi Pengambilan Sampel penelitian (sumber : Citra Google Map)

\section{Peralatan}

Alat yang dipergunakan pada penelitian ini antara lain adalah sebagai berikut :

1. Komputer atau laptop (Notebook)

2. GPS (Global Positioning System)

3. Water checker

4. Alat laboratorium pengujian Air

5. Perahu atau kapal

6. Software pengolahan citra dan SIG

\section{Bahan}

Bahan yang akan digunakan pada penelitian ini adalah sebagai berikut :
1. Data citra MODIS untuk menghitung suhu permukaan laut dan klorofil-a.

2. Peta RBI skala 1 : 1.000 .000 untuk proses geometrik citra satelit.

3. Data parameter oseanografi (suhu permukaan laut) in-situ.

\section{Pengolahan Data}

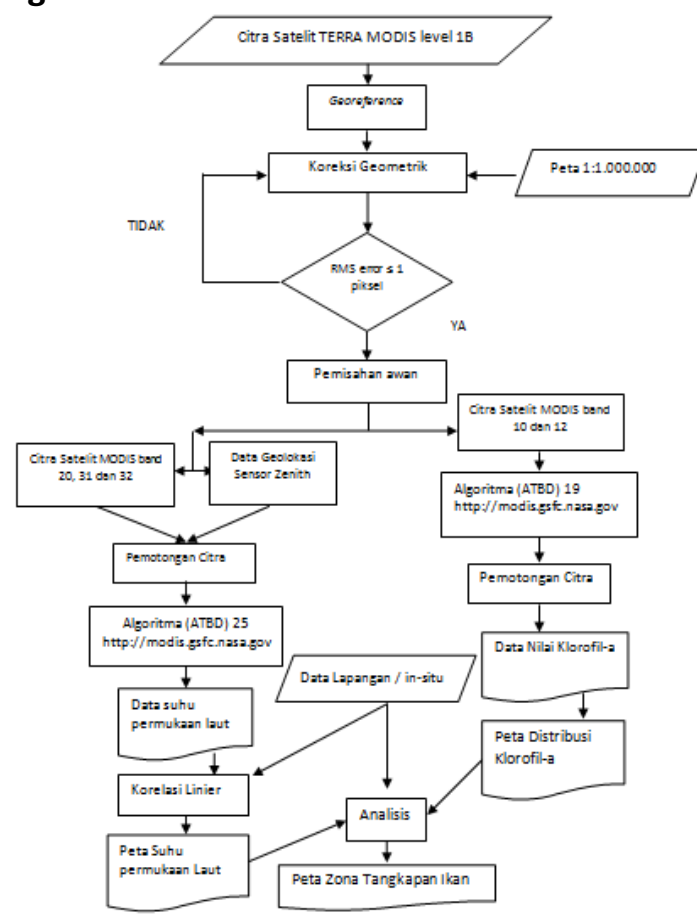

Gambar 2. Diagram Alir Pengolahan Citra

1. Algoritma MODIS untuk Klorofil

\section{Penerapan Algoritma ATBD 19}

Algoritma yang digunakan dalam pengolahan nilai konsentrasi klorofil yang mengacu pada Algorithm Theoretical Basic Document Modis 19 (ATBD 19) dengan persamaan sebagai berikut:

$$
R=\log \left(\frac{R r s 488}{R r s 551}\right)
$$

Dengan $C$ didefinisikan sebagai nilai kandungan klorofil, Rrs 551 didefinisikan sebagai nilai reflektansi permukaan pada panjang gelombang $551 \mathrm{~nm}$, pada citra satelit MODIS Aqua nilai reflektansi ini diwakili oleh kanal 12, Rrs 488 didefinisikan sebagai nilai reflektansi permukaan pada panjang gelombang $488 \mathrm{~nm}$, pada citra satelit MODIS Aqua nilai reflektansi ini diwakili oleh kanal 10. 
2. Algoritma MODIS untuk Suhu Permukaan Laut Penerapan Algoritma ATBD 25

Algoritma yang digunakan dalam pengolahan suhu permukaan laut yang mengacu pada Algorithm Theoretical Basic Document Modis 25 (ATBD 25) dengan persamaan sebagai berikut:

$$
\mathrm{SPL}=\mathrm{c} 1+\mathrm{c} 2 *(\mathrm{~T} 31-273)+\mathrm{c} 3 *(\mathrm{~T} 31-\mathrm{T} 32) *(\mathrm{~T} 20-
$$$$
\text { 273) }+c 4 *(T 31-T 32) *(1 / \cos \theta-1)
$$

\section{Dimana :}

T20 adalah tingkat kecerahan suhu band 20 (BT) T31 adalah tingkat kecerahan suhu band 31 (BT) T32 adalah tingkat kecerahan suhu band 32 (BT) c1, c2, c3 dan c4 adalah koefisien suhu permukaan laut

$\theta$ adalah sudut zenith satelit

Tabel 1. Koefisien untuk MODIS band 31 dan 32 Algoritma SPL (Sumber : Brown and Minnet, 1999)

\begin{tabular}{|l|l|l|}
\hline Koefisien & $\boldsymbol{\Delta} \mathbf{T} \leq \mathbf{0 . 7}$ & $\boldsymbol{\Delta} \mathbf{T} \mathbf{0 . 7}$ \\
\hline C1 & 1,228552 & 1,692521 \\
\hline C2 & 0,9576555 & 0,9558419 \\
\hline C3 & 0,1182196 & 0,0873754 \\
\hline C4 & 1,774631 & 1,199584 \\
\hline
\end{tabular}

Sehingga, untuk menghitung suhu permukaan laut, band harus dikonversi menjadi suhu kecerahan air dahulu dengan menggunakan persamaan invers fungsi Planck yaitu sebagai berikut :

$$
T b=c 2 /\left(V i * \ln \left(c 1 /\left(V i^{5} * \text { radiansi }\right)+1\right)\right)
$$

\section{Dimana}

$\begin{array}{rll}\mathrm{Tb}= & \text { suhu kecerahan air }\left({ }^{\circ} \mathrm{K}\right) \\ \mathrm{c} 1, \mathrm{c} 2= & \text { konstanta radiasi, dimana nilai c1 } \\ \text { adalah } 1,1910659 \times 10^{8}\left[\mathrm{~W} \mathrm{~m}^{-2} \mathrm{sr}^{-1}\right. & \left.\left(\mu \mathrm{m}^{-1}\right)^{-4}\right], \text { dan nilai c2 adalah } \\ & 1,438833 \times 10^{4}[\mathrm{~K} \mu \mathrm{m}] \\ \mathrm{Vi}= & \begin{array}{l}\text { panjang gelombang pusat (central } \\ \text { wavelength), } \\ \text { merupakan band MODIS yang } \\ \text { akan dihitung nilai suhu } \\ \text { kecerahan airnya. }\end{array}\end{array}$

\section{Teori Terkait}

Pada penelitian Adnan 2010 dengan judul penelitian "Analisis Suhu Permukaan Laut Dan Klorofil-A Data Inderaja Hubungannya Dengan Hasil Tangkapan Ikan Tongkol (Euthynnus Affinis)
Di Perairan Kalimantan Timur ", hasil analisis menunjukkan adanya tendensi dimana SPL yang rendah menghasilkan tangkapan yang relatif tinggi. Sebaliknya, dengan SPL yang tinggi, maka hasil tangkapan cenderung menurun kondisi suhu permukaan laut hubungannnya dengan hasil tangkapan terlihat bahwa penurunan suhu permukaan laut terdapat hasil tangkapan yang meningkat begitu juga sebaliknya, peningkatan suhu permukaan laut menyebakan penurunan hasil tangkapan. Suhu rendah ini berkisar antara $26^{\circ} \mathrm{C}-30^{\circ} \mathrm{C}$. Hubungan konsentrasi klorofil-a dengan hasil tangkapan ikan tongkol terlihat bahwa meningkatnya konsentrasi klorofil-a terdapat hasil tangkapan yang meningkat, begitu juga sebaliknya penurunan konsentrasi klorofil-a terdapat hasil tangkapan ikan yang menurun.

\section{HASIL DAN PEMBAHASAN}

\section{Hasil Pengolahan Suhu Permukaan Laut}

Pada penelitian ini, menggunakan kombinasi band emisiv 20, 31 dan 32 disertai data sensor zenith citra untuk mendapatkan suhu permukaan laut. Citra yang diolah yaitu pada tahun 2016 dari maret, april, juli, september dan oktober.

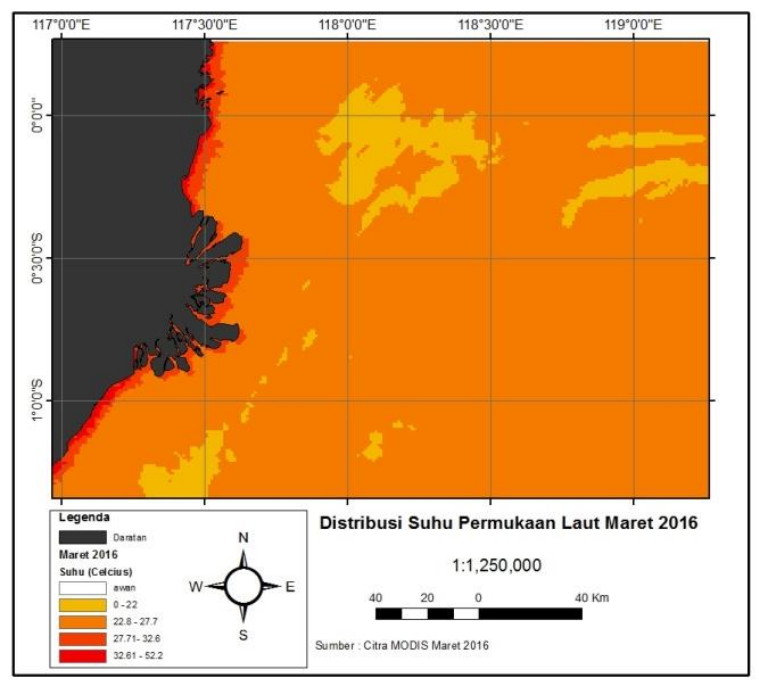

Gambar 3. Hasil Pengolahan Suhu Permukaan Laut Bulan Maret 2016

Pada bulan maret 2016, suhu permukaan laut hasil citra menunjukkan suhu permukaan laut pada bulan ini rata-rata dengan suhu sedang berkisar antara $22^{\circ} \mathrm{C}$ sampai dengan $27^{\circ} \mathrm{C}$ dengan besaran suhu rata-rata $24^{\circ} \mathrm{C}$. Daerah suhu dominasi ini tersebar di daerah tengah selat 
Makassar. Untuk suhu yang tinggi berkisar $28^{\circ} \mathrm{C}$ sampai dengan $32{ }^{\circ} \mathrm{C}$, tersebar sedikit di pesisir sekitar delta Mahakam. Suhu yang relatif rendah yang berkisar $0^{\circ} \mathrm{C}$ sampai dengan $22^{\circ} \mathrm{C}$ banyak terdapat di daerah tengah selat Makassar.

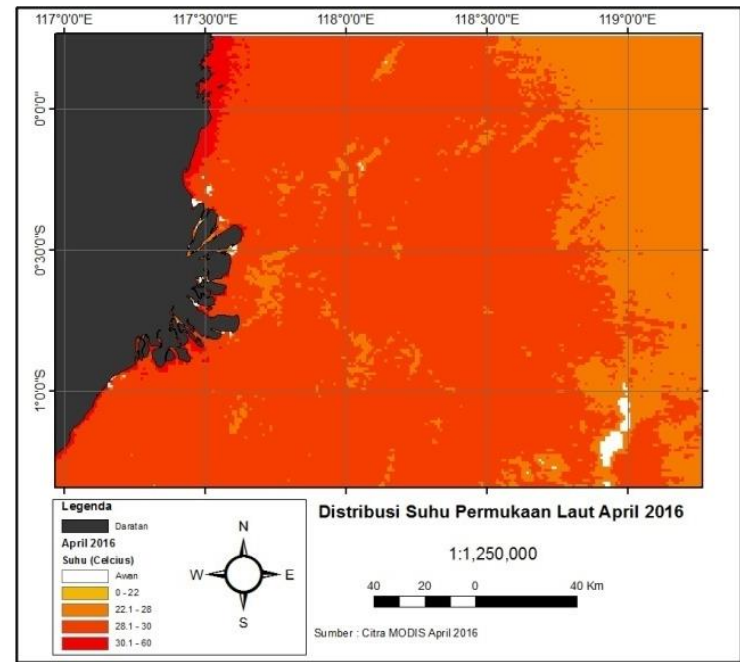

Gambar 4. Hasil Pengolahan Suhu Permukaan Laut Bulan April 2016

Pada bulan april 2016, suhu permukaan laut hasil citra menunjukkan suhu permukaan laut pada bulan ini rata-rata dengan suhu tinggi berkisar antara $28^{\circ} \mathrm{C}$ sampai dengan $30^{\circ} \mathrm{C}$ dengan besaran suhu rata-rata $25{ }^{\circ} \mathrm{C}$. Daerah suhu dominasi ini tersebar dari pesisir delta Mahakam sampai daerah tengah selat Makassar. Untuk suhu yang sedang berkisar $22^{\circ} \mathrm{C}$ sampai dengan $27^{\circ} \mathrm{C}$, tersebar banyak di pesisir sekitar pulau Sulawesi. Suhu yang relatif rendah yang berkisar $0{ }^{\circ} \mathrm{C}$ sampai dengan $22{ }^{\circ} \mathrm{C}$ sangat sedikit dan tersebar disekitar awan.

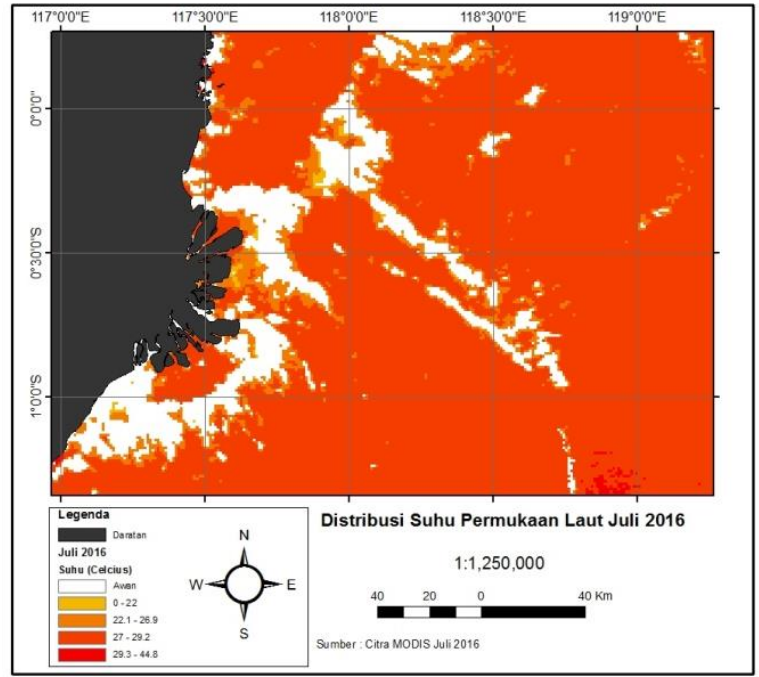

\section{Gambar 5. Hasil Pengolahan Suhu Permukaan} Laut Bulan Juli 2016

Pada bulan Juli 2016, banyak daerah yang tertutup oleh awan sehingga suhu permukaan lautnya tidak terhitung. Suhu permukaan laut yang tidak tertutup awan pada bulan ini rata-rata dengan suhu tinggi berkisar antara $27^{\circ} \mathrm{C}$ sampai dengan $29^{\circ} \mathrm{C}$. Daerah suhu dominasi ini tersebar di daerah tengah selat Makassar. Untuk suhu yang sedang berkisar $22{ }^{\circ} \mathrm{C}$ sampai dengan $27{ }^{\circ} \mathrm{C}$, tersebar banyak di pesisir delta Mahakam. Suhu yang relatif rendah yang berkisar $0{ }^{\circ} \mathrm{C}$ sampai dengan $22{ }^{\circ} \mathrm{C}$ sangat sedikit dan tersebar disekitar awan.

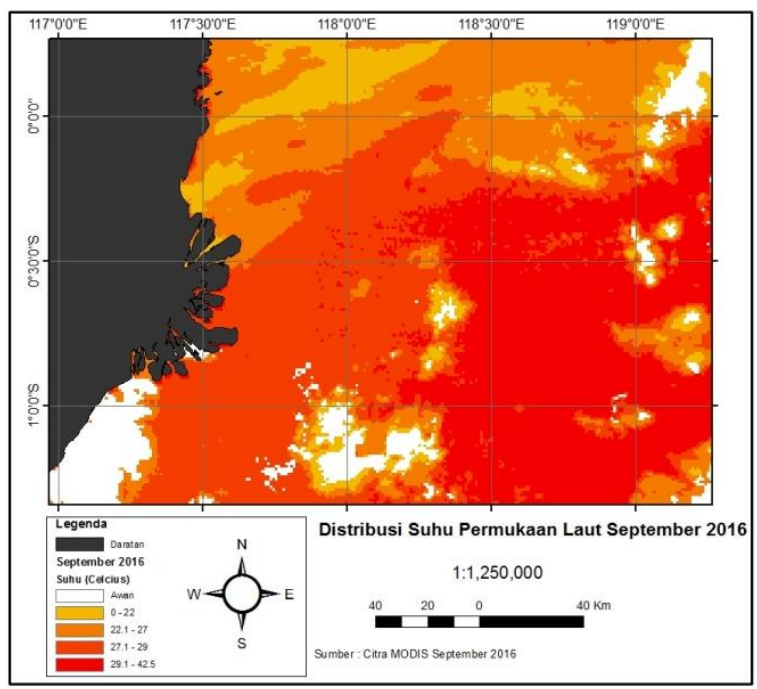

Gambar 6. Hasil Pengolahan Suhu Permukaan Laut Bulan September 2016

Pada bulan September 2016, juga terdapat banyak daerah yang tertutup oleh awan seperti pada bulan juli. Suhu permukaan laut hasil citra menunjukkan suhu permukaan laut pada bulan ini rata-rata dengan suhu sangat tinggi berkisar antara $29^{\circ} \mathrm{C}$ sampai dengan $42^{\circ} \mathrm{C}$. Daerah suhu dominasi ini tersebar di daerah tengah selat Makassar. Untuk suhu yang tinggi berkisar $27{ }^{\circ} \mathrm{C}$ sampai dengan $29{ }^{\circ} \mathrm{C}$, tersebar banyak di pesisir delta Mahakam sampai ke tengah selat. Suhu yang relatif rendah yang berkisar $0{ }^{\circ} \mathrm{C}$ sampai dengan $22{ }^{\circ} \mathrm{C}$ tersebar di bagian utara selat Makasar dan disekitar awan dan ini sama seperti suhu rendah yang tersebar juga di bagian utara selat.

Pada bulan oktober 2016, juga terdapat banyak daerah yang tertutup oleh awan seperti pada bulan September, akan tetapi pada bulan ini 
lebih banyak. Suhu permukaan laut hasil citra menunjukkan suhu permukaan laut pada bulan ini merata dengan suhu tinggi berkisar antara $27^{\circ} \mathrm{C}$ sampai dengan $29^{\circ} \mathrm{C}$ tersebar di daerah tengah selat Makassar. Untuk suhu yang sedang berkisar $22{ }^{\circ} \mathrm{C}$ sampai dengan $27{ }^{\circ} \mathrm{C}$, tersebar banyak di pesisir delta Mahakam sampai ke bagian atas selat Makasar. Suhu yang relatif rendah yang berkisar $0{ }^{\circ} \mathrm{C}$ sampai dengan $22{ }^{\circ} \mathrm{C}$ tersebar di bagian utara selat Makasar, pesisir delta Mahakam dan disekitar awan.

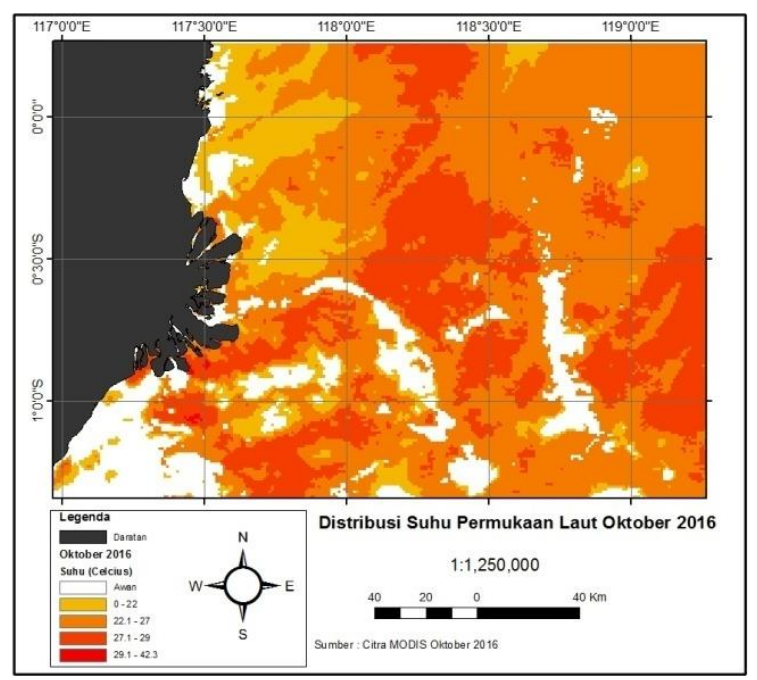

Gambar 7. Hasil Pengolahan Suhu Permukaan Laut Bulan Oktober 2016

\section{Hasil Pengolahan Klorofil-a}

Pada penelitian ini, citra TERRA MODIS yang digunakan untuk menghitung sebaran klorofil-a dalam penelitian ini yaitu citra pada bulan Maret, April, Juli, September dan Oktober 2016. Data bulan ini digunakan karena citra ini terdapat sedikit tutupan awan. Pada bulan Maret 2016, sebaran klorofil-a menunjukkan nilai klorofil-A tinggi tersebar di tengah selat Makassar bagian tengah dekat pulau Sulawesi, sedangkan untuk pesisir delta Mahakam tersebar di sebelah selatan. Pada bulan ini, sebaran klorofil-a tinggi yang teridentifikasi ini hanya berjumlah sedikit.

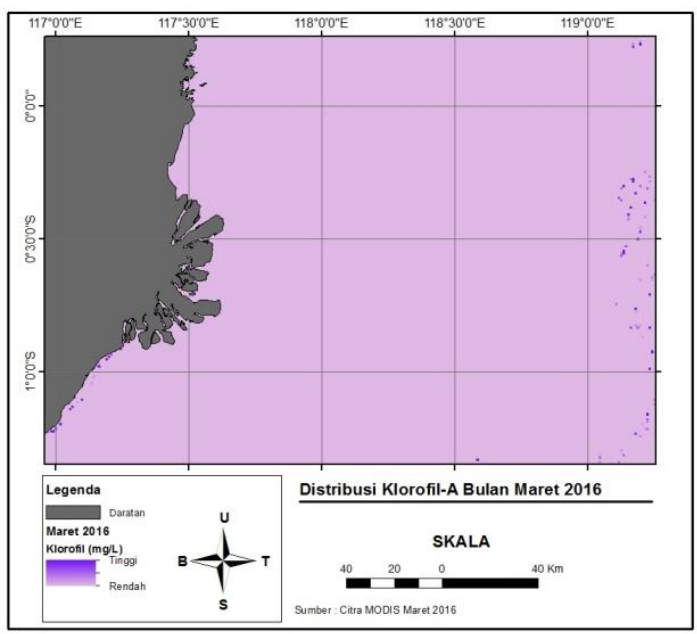

Gambar 8. Hasil Pengolahan Klorofil-A Bulan Maret 2016

Sebaran klorofil-A pada bulan April 2016 menunjukkan nilai klorofil-A tinggi sedikit tersebar di tengah selat Makassar bagian tengah, sedangkan untuk pesisir delta Mahakam tersebar di sebelah utara. Pada bulan ini, sebaran klorofil-a tinggi yang teridentifikasi ini hanya berjumlah sedikit. Pada bulan Juli 2016, sebaran klorofil-a menunjukkan klorofil-A banyak teridentifikasi dengan nilai klorofil-A tinggi tersebar di tengah selat Makassar bagian tengah dan untuk pesisir delta Mahakam tersebar di sebelah utara sampai selatan. Rata-rata nilai dari klorofil-A pada bulan ini berkisar antara 0,022266 mg/L .

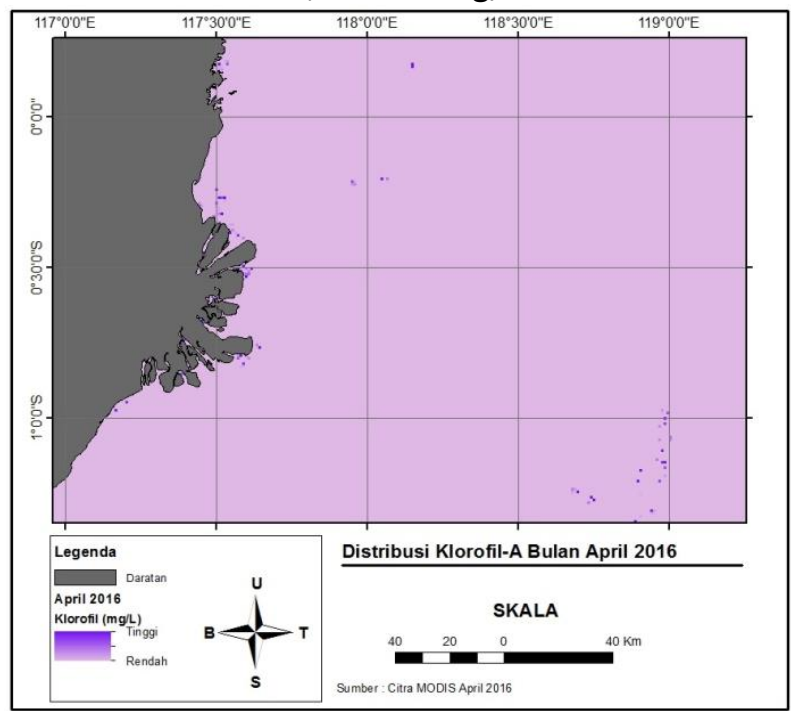

Gambar 9. Hasil Pengolahan Klorofil-A Bulan April 2016 

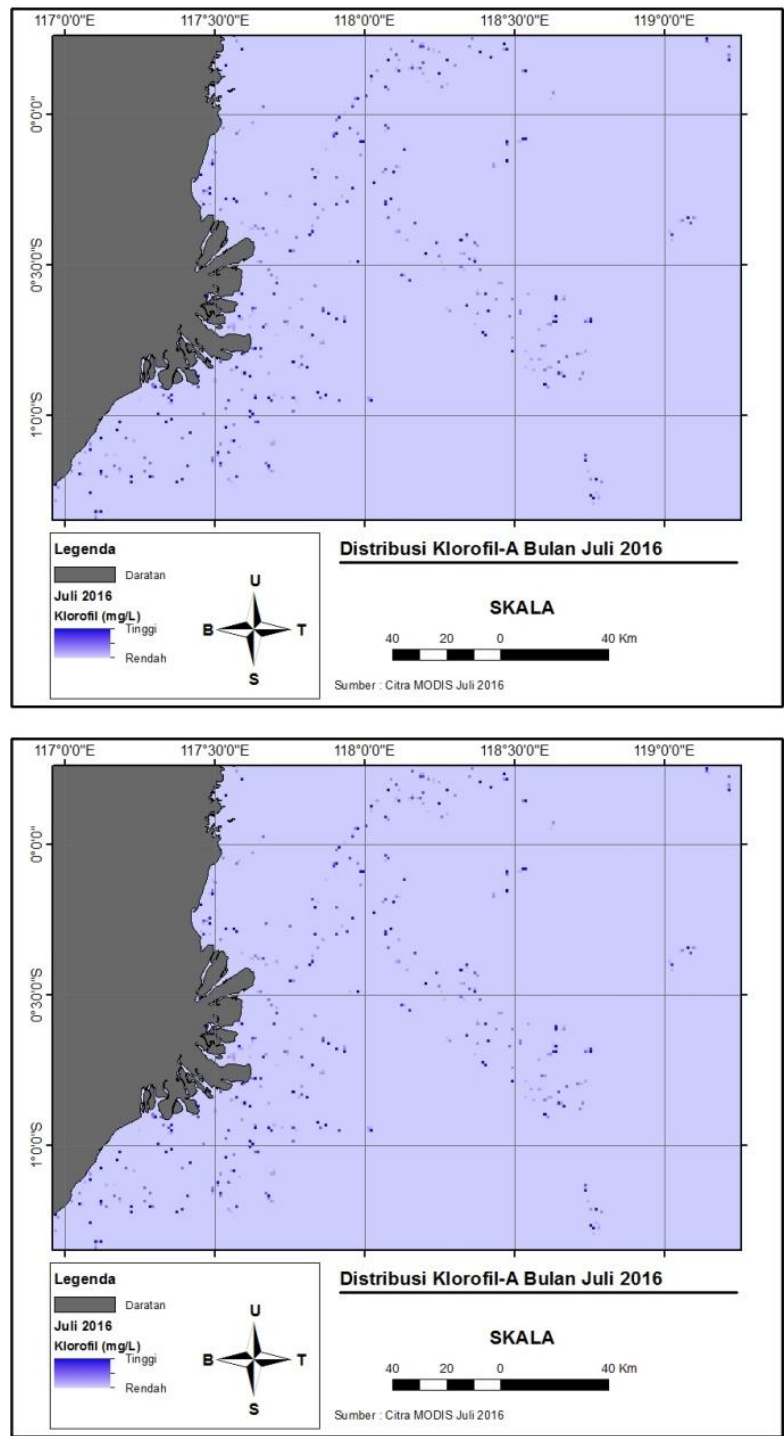

Gambar 10. Hasil Pengolahan Klorofil-A Bulan Juli 2016

Pada bulan September 2016, sebaran klorofil-a menunjukkan klorofil-A sedikit teridentifikasi dengan nilai klorofil-A tinggi tersebar di pesisir delta Mahakam tersebar di sebelah selatan. Pada bulan ini, sebaran klorofil-a tinggi yang teridentifikasi ini hanya berjumlah sedikit. Pada bulan Oktober 2016, sebaran klorofil-a menunjukkan klorofil-A banyak teridentifikasi dengan nilai klorofil-A tinggi tersebar di pesisir delta Mahakam tersebar di sebelah selatan dan di selat Mahakam bagian selatan. Pada bulan ini, sebaran klorofil-a tinggi yang teridentifikasi ini hanya berjumlah banyak.

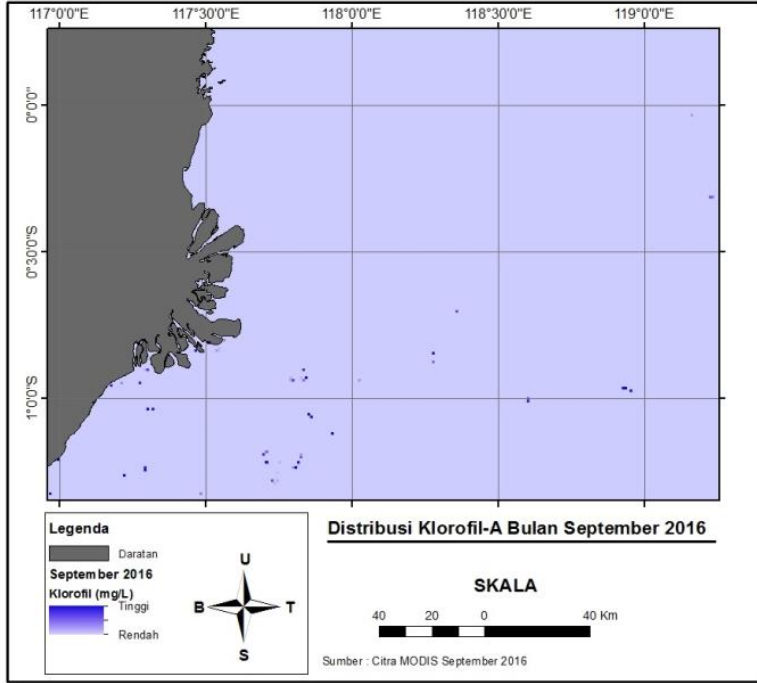

Gambar 11. Hasil Pengolahan Klorofil-A Bulan September 2016

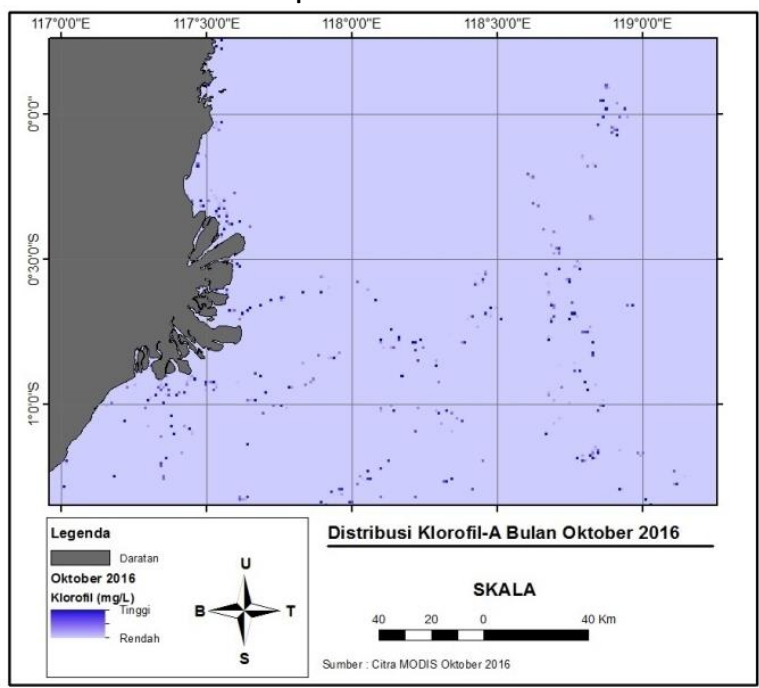

Gambar 12. Hasil Pengolahan Klorofil-A Bulan September 2016

\section{Analisi Prediksi Daerah Potensi Tangkapan Ikan}

Pada penelitian ini, acuan yang digunakan untuk membuat zonasi daerah potensi tangkapan ikan yaitu dari penelitian Adnan 2010. Potensi zona tangkapan banyak ikan memiliki suhu permukaan laut sekitar $27^{\circ} \mathrm{C}-30^{\circ} \mathrm{C}$ dengan nilai klorofil-a nya tinggi, sehingga apabila kondisi suhu permukaan laut dan klorofil-a tidak sesuai langsung diidentifikasi menjadi zona tangkapan sedikit ikan. Analisis untuk penentuan zona dilakukan dengan melihat data hasil pengolahan citra suhu permukaan laut serta klorofil-a dan disesuaikan dengan klasifikasi zona, kemudian diberi tanda spot zona.

Pada tahun 2016, citra yang digunakan yaitu citra pada bulan maret, april, juli, agustus, dan 
oktober. Suhu permukaan laut pada bulan-bulan ini rata-rata $27^{\circ} \mathrm{C}$ sampai dengan $30^{\circ} \mathrm{C}$, hanya pada bulan maret yang suhu permukaan lautnya rata-rata suhu yang lebih rendah. Sebaran klorofila pada tahun ini teridentifikasi sedikit pada bulan September, april dan maret, sedangkan pada bulan oktober dan juli banyak teridentifikasi klorofil-a. Pada tahun ini, tingkat kesuburan perairannya relatif merata, pada bulan oktober, september dan juli klorofil-a yang teridentifikasi banyak dan bulan april dan maret klorofil-a yang teridentifikasi sedikit. Pada tahun ini, terdapat zona banyak tangkapan ikan dan zona sedikit tangkapan ikan. Zona rendah tangkapan ikan tersebar di sebelah utara dan tengah delta Mahakam, serta di tengah selat makasar. Zona tinggi tangkapan ikan tersebar di sebelah selatan delta Mahakam, serta di tengah selat makasar. Pemaparan ini bisa dilihat pada gambar peta di bawah ini. (Peta Asli di lampiran)

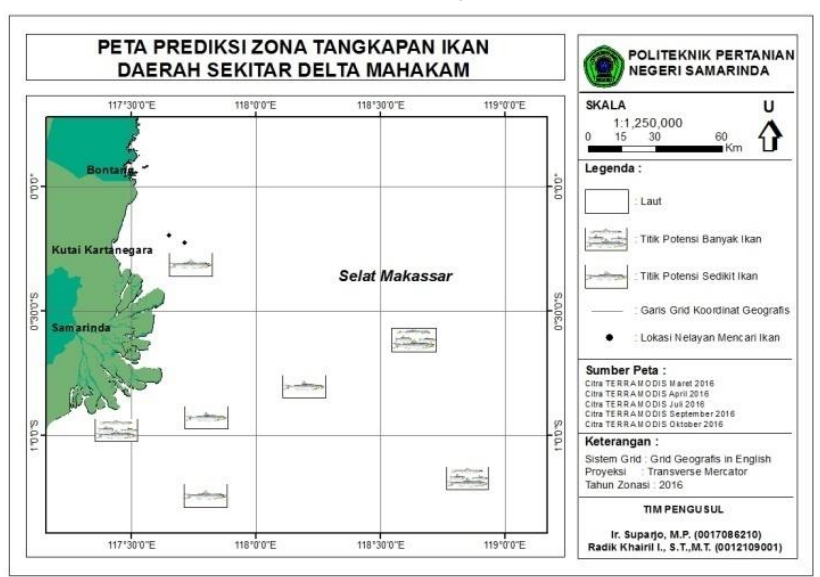

Gambar 13. Gambar Peta Zona Tangkapan Ikan Tahun 2016

\section{Hubungan Data Lapangan dan hasil Pengolahan citra satelit}

Pengambilan data pada penelitian ini sebanyak 15 titik lokasi sampel air yang diambil pada tanggal 4 Juni 2016. Citra Terra MODIS yang didownload dan dilakukan pengolahan merupakan data citra satelit rekaman 4 Juni 2016 pukul 02.30 WIB. Hasil pengolahan SPL yang dilakukan menunjukkan nilai SPL yang tampak pada tabel berikut :

Tabel 2. Perbandingan Data Lapangan dan hasil Pengolahan citra satelit

\begin{tabular}{|c|c|c|c|c|c|c|}
\hline \multirow[b]{2}{*}{ No. } & \multirow{2}{*}{$\begin{array}{l}\text { Nama } \\
\text { Titik }\end{array}$} & \multicolumn{2}{|c|}{ Koordinat Lokasi } & \multicolumn{3}{|c|}{$\operatorname{SPL}\left({ }^{\circ} \mathrm{C}\right)$} \\
\hline & & $\begin{array}{l}\text { Lintang } \\
\left({ }^{\circ}\right)\end{array}$ & $\begin{array}{l}\text { Bujur } \\
\left({ }^{\circ}\right)\end{array}$ & $\begin{array}{c}\text { Data } \\
\text { Insit } \\
\text { u }\end{array}$ & $\begin{array}{l}\text { Data } \\
\text { citra }\end{array}$ & Selisih \\
\hline 1 & P1 & $\begin{array}{l}0,30216 \\
\text { LS }\end{array}$ & $\begin{array}{l}117,61 \\
329 \text { BT } \\
\end{array}$ & 30 & 26.8 & 3.2 \\
\hline 2 & $\mathrm{P} 2$ & $\begin{array}{l}0,28800 \\
\text { LS }\end{array}$ & $\begin{array}{l}117,61 \\
395 \text { BT } \\
\end{array}$ & 30 & 26.8 & 3.2 \\
\hline 3 & P3 & $\begin{array}{l}0,27463 \\
\text { LS }\end{array}$ & $\begin{array}{l}117,61 \\
450 \text { BT } \\
\end{array}$ & 30 & 26.7 & 3.3 \\
\hline 4 & P4 & $\begin{array}{l}0,26194 \\
\text { LS }\end{array}$ & $\begin{array}{l}117,61 \\
536 \mathrm{BT}\end{array}$ & 30 & 26.6 & 3.4 \\
\hline 5 & P5 & $\begin{array}{l}0,24916 \\
\text { LS }\end{array}$ & $\begin{array}{l}117,61 \\
674 \text { BT } \\
\end{array}$ & 30 & 26.7 & 3.3 \\
\hline 6 & P6 & $\begin{array}{l}0,23611 \\
\text { LS }\end{array}$ & $\begin{array}{l}117,61 \\
697 \text { BT }\end{array}$ & 30.1 & 27.3 & 2.8 \\
\hline 7 & P7 & $\begin{array}{l}0,22241 \\
\text { LS }\end{array}$ & $\begin{array}{l}117,61 \\
837 \text { BT } \\
\end{array}$ & 30 & 26.4 & 3.6 \\
\hline 8 & P8 & $\begin{array}{l}0,20984 \\
\text { LS }\end{array}$ & $\begin{array}{l}117,61 \\
912 \text { BT } \\
\end{array}$ & 30 & 26.8 & 3.2 \\
\hline 9 & P9 & $\begin{array}{l}\text { 0,19708 } \\
\text { LS }\end{array}$ & $\begin{array}{l}117,62 \\
046 \text { BT }\end{array}$ & 30 & 26.6 & 3.4 \\
\hline 10 & P10 & $\begin{array}{l}0,18479 \\
\text { LS }\end{array}$ & $\begin{array}{l}117,62 \\
009 \text { BT }\end{array}$ & 30 & 26.5 & 3.5 \\
\hline 11 & P11 & $\begin{array}{l}0,18807 \\
\text { LS }\end{array}$ & $\begin{array}{l}117,63 \\
790 \text { BT }\end{array}$ & 30 & 26.6 & 3.4 \\
\hline 12 & P12 & $\begin{array}{l}0,19900 \\
\text { LS }\end{array}$ & $\begin{array}{l}117,63 \\
610 \text { BT } \\
\end{array}$ & 30 & 26.7 & 3.3 \\
\hline 13 & P13 & $\begin{array}{l}0,20994 \\
\text { LS }\end{array}$ & $\begin{array}{l}117,63 \\
439 \text { BT }\end{array}$ & 30 & 26.9 & 3.1 \\
\hline 14 & P14 & $\begin{array}{l}0,22114 \\
\text { LS }\end{array}$ & $\begin{array}{l}117,63 \\
253 \text { BT }\end{array}$ & 30 & 27.1 & 2.9 \\
\hline 15 & P15 & $\begin{array}{l}0,23367 \\
\text { LS }\end{array}$ & $\begin{array}{l}117,63 \\
215 \mathrm{BT}\end{array}$ & 30 & 26.8 & 3.2 \\
\hline
\end{tabular}

Dari tabel 2 yang menunjukan nilai suhu permukaan laut pada 15 titik sampel dapat dihitung nilai korelasi antara SPL hasil pengolahan citra satelit dengan SPL lapangan. Nilai SPL yang ditunjukkan memiliki perbedaan secara keseluruhan dan dari hasil perhitungan diperoleh nilai korelasi antara SPL hasil pengolahan citra satelit dengan SPL lapangan sebesar $44.64 \%$ dengan nilai koefisien determinasi sebesar $R^{2}=$ 0.4464. Nilai ini menunjukkan tingkat kesamaan pola dari nilai SPL yang dihitung dengan yang diukur dilapangan. Hubungan pola yang diperoleh dari nilai korelasi ini menunjukkan hubungan yang kurang kuat antara nilai SPL hasil pengolahan citra satelit dengan SPL lapangan karena kurang dari 50 $\%$.

Pada penelitian ini, nilai perbedaan terbesar terletak pada titik P7 yaitu sebesar $3,6^{\circ} \mathrm{C}$ dan perbedaan terkecil terletak pada $\mathrm{P} 6$ yaitu sebesar $2,8{ }^{\circ} \mathrm{C}$. Perbedaan diakibatkan oleh sifat suhu 
permukaan yang dinamis dimana faktor terbesar yang mempengaruhi nilai suhu adalah radiasi matahari. Selain sifat SPL yang dinamis, perbedaan suhu ini juga dipengaruhi oleh perbedaan waktu pengambilan data dimana data citra yang merekam area yang sama dengan area titik sampel pada dini hari sekitar pukul 02.30 WIB sedangkan pengambilan data sampel dilapangan dilakukan pada siang hari pukul 09:30 - 12:00 WITA.

Nilai yang diperoleh juga terkait dengan algoritma yang digunakan dimana pada penelitian ini digunakan algoritma ATBD 25 yang tersedia pada MODIS. Sebuah algoritma disusun berdasar bentuk keterkaitan matematis antara data sampel yang ada dilapangan dengan data digital number yang ada pada image citra satelit. Hal ini menjadikan hasil yang diperoleh dengan menggunakan algoritma tertentu tidak bersifat global. Nilai SPL yang diperoleh menunjukkan adanya perbedaan yang mencapai $3.6^{\circ} \mathrm{C}$. Perbedaan ini menunjukkan bahwa algoritma ATBD 25 kurang cocok untuk digunakan dalam pengukuran SPL di daerah ekuator.

\section{PENUTUP}

\section{Kesimpulan}

Berdasarkan dari penelitian tentang kajian tentang penentuan daerah tangkapan ikan dengan menggunakan parameter distribusi spasial suhu permukaan laut dan distribusi klorofil-a di perairan delta mahakam, dapat diambil kesimpulan:

1. Suhu permukaan laut pada penelitian ini rata-rata $27^{\circ} \mathrm{C}$ sampai dengan $30^{\circ} \mathrm{C}$, hanya pada bulan maret yang suhu permukaan lautnya rata-rata suhu yang lebih rendah.

2. Sebaran klorofil-a pada penelitian ini teridentifikasi sedikit pada bulan September, april dan maret, sedangkan pada bulan oktober dan juli banyak teridentifikasi klorofil-a. Pada tahun ini, tingkat kesuburan perairannya relatif merata, pada bulan oktober, september dan juli klorofil-a banyak dan bulan april dan maret klorofil-a yang teridentifikasi sedikit

3. Pada penelitian ini, terdapat zona tinggi tangkapan ikan dan zona rendah tangkapan ikan dengan acuan dari penelitian Adnan,
2010. Zona rendah tangkapan ikan tersebar di sebelah utara dan tengah delta Mahakam, serta di tengah selat makasar. Zona tinggi tangkapan ikan tersebar di sebelah selatan delta Mahakam, serta di tengah selat makasar.

\section{Saran}

Saran yang dapat diberikan oleh penulis berdasarkan penelitian yang dilakukan yaitu perlu adanya waktu yang cukup lama untuk menyelesaikan penelitian tersebut dikarena mencari data citra satelit yang bersih dari awan sangat sulit dan harus dicek perbulannya serta kondisi cuaca yang tidak mendukung untuk penggambilan data cek lapangan (ground truth) sehingga memakan waktu yang lama untuk mencari kondisi cuaca yang bagus untuk cek lapangan (ground truth). Penggunaan algoritma juga perlu diperhatikan dikarenakan kesesuaian algoritma dengan daerah penelitian dapat mempengaruhi penelitian. Untuk pembuatan zonasi lebih baik ditambahkan dengan data hasil tangkapan ikan sehingga data lebih valid sesuai lapangan.

\section{DAFTAR PUSTAKA}

Adnan. (2010). Analisis Suhu Permukaan Laut Dan Klorofil-A Data Inderaja Hubungannya Dengan Hasil Tangkapan Ikan Tongkol (Euthynnus affinis) $\mathrm{Di}$ Perairan Kalimantan Timur. Jurnal "Amanisal" PSP FPIK Unpatti-Ambon. Vol. 1. No.1, Mei 2010. Hal 1- 12 .

Brown, O. B dan P. J. Minnet. (1999). MODIS Infrared Sea Surface Temperature Algorithm. ATBD Version 2.0. Hal 5. University of Miami. Miami. VII $+98 \mathrm{~h}$.

Dinas Kelautan dan Perikanan di Kutai Kartanegara 2013

Janssen, L.F.L and Huurneman C.G. (2001). Principles of Remote Sensing. ITC Educational Texbooks Series. ITC, Enshede, Netherlands.

MODIS. (2005). Handbook MODIS. http://www.MODIS.gsfc.nasa.gov

Murrachman. (2006). Diktat Kuliah Fish Handling. Jilid I. Fakultas Perikanan. Universitas Brawijaya. Malang. 


PETA PREDIKSI ZONA TANGKAPAN IKAN
DAERAH SEKITAR DELTA MAHAKAM

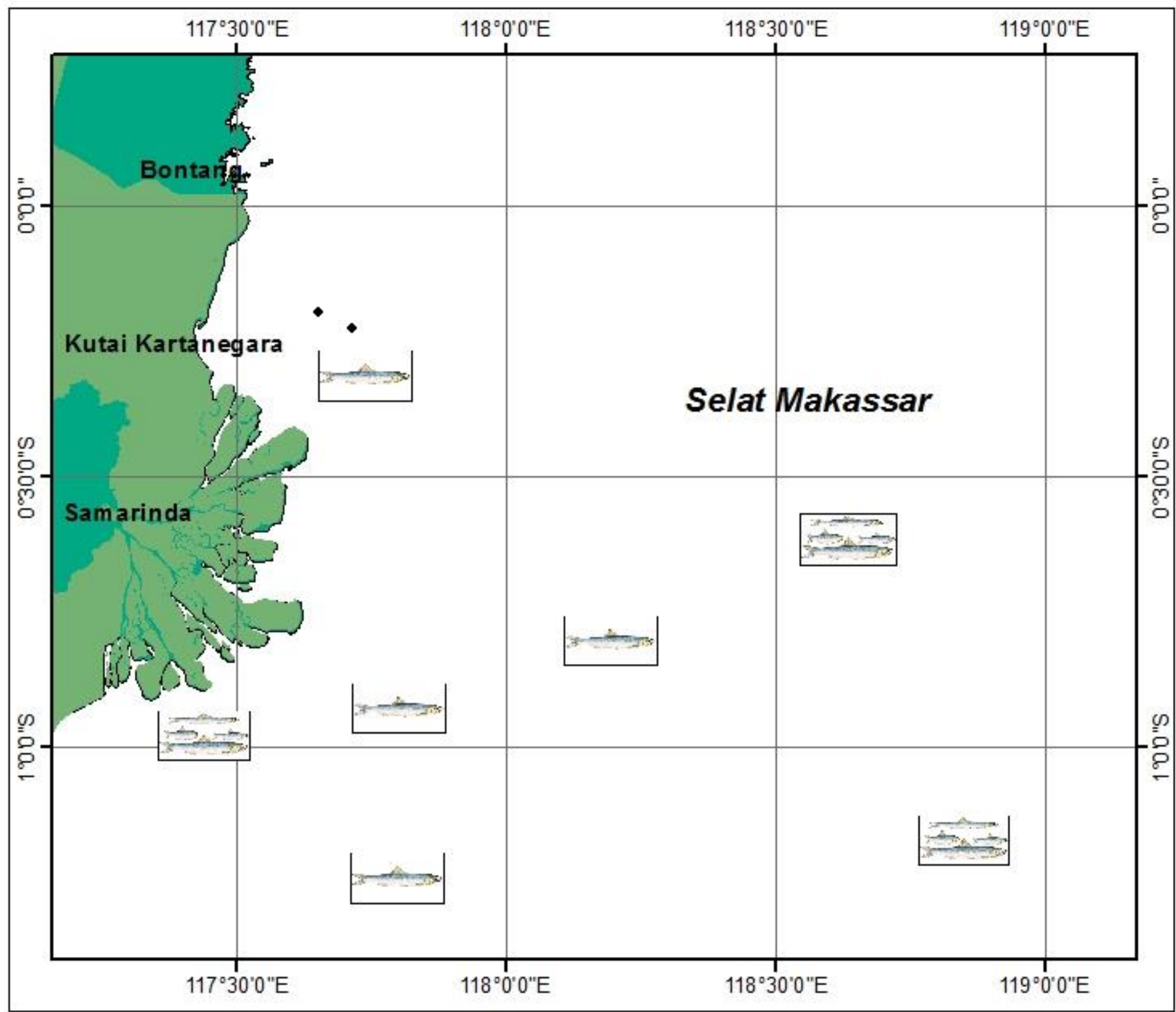

POLITEKNIK PERTANIAN NEGERI SAMARINDA

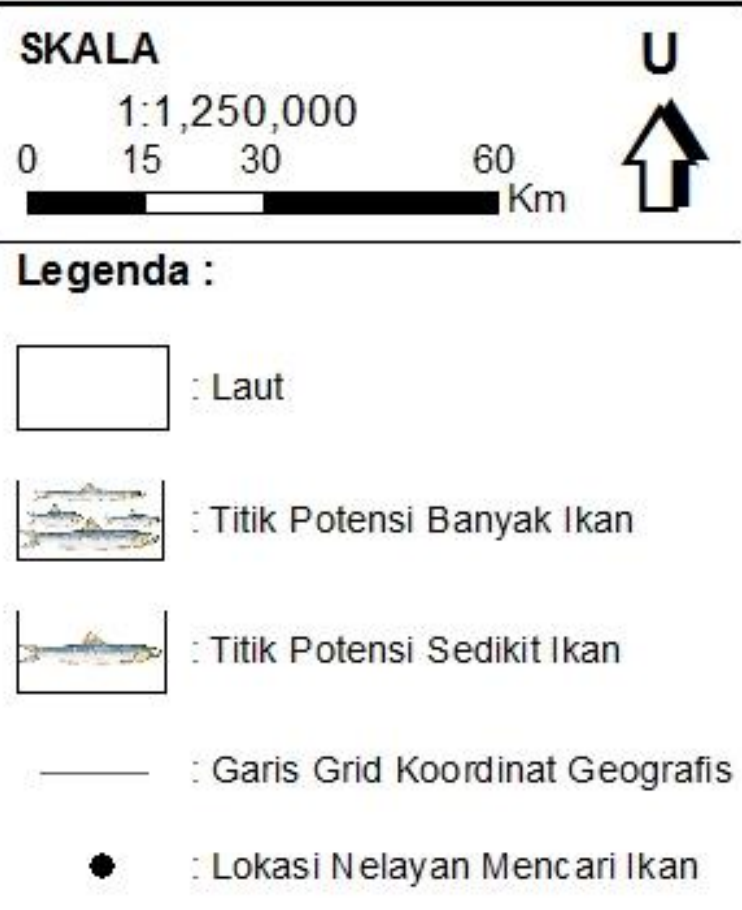

\section{Sumber Peta :}

Citra TERRA M ODIS M aret 2016

Citra TERRAM ODIS April 2016

Citra TERRAM ODIS Juli 2016

Citra TERRAM ODIS September 2016

Citra TERRA M O DIS Oktober 2016

\section{Keterangan :}

Sistem Grid : Grid Geografis in English Proyeksi : Transverse Mercator

Tahun Zonasi : 2016

\section{TIM PENGUSUL}

Ir. Suparjo, M.P. (0017086210)

Radik Khairil I., S.T.,M.T. (0012109001) 